\title{
Boarding School Character Development for Character Discipline and Responsibility
}

\author{
Sefta Nugraha Dwiputra ${ }^{1,{ }^{*}}$ Muhammad Halimi ${ }^{2}$ \\ 1,2 Universitas Pedidikan Indonesia \\ "Corresponding author.Email: seftanugraha@upi.edu
}

\begin{abstract}
This study discusses the role of boarding schools in character building discipline and responsibility. Many problems are related to the character of discipline and responsibility, such as not complying with rules such as traffic regulations, physical distancing regulations during the pandemic. This researcher examines how programs and activities at boarding schools are an effort to foster disciplined character and responsibility. The relevance of this research in civic education is to instill the character of responsibility, which is part of a good citizen, while the character of discipline is the beginning of the character of responsibility. Civic education has something in common with character education and religious education, namely that it is interconnected with one another. This study uses a qualitative method as an approach because the research results can be done descriptively, and the research method uses a case study because it examines a school specifically, and uses interviews, observation, and documentation methods. Analysis of research data using data reduction, data presentation, and conclusion. Data verification uses source triangulation, techniques, and member checks. This research was carried out at the Baituilmi boarding school because the boarding school has good discipline and responsibility development through habituation and activities such as reading the Quran, Tahajud prayer activities. The results of the research show that students who study at the Baituilmi boarding school are more disciplined in carrying out activities and are more responsible in various tasks and activities, they live in the dormitory for one full day so that there are no bad influences from outside that can affect them.
\end{abstract}

\section{Keywords: Boarding School, Discipline Character, Responsibility Character.}

\section{INTRODUCTION}

Education does not only refer to knowledge but also pays attention to aspects of character, values, morals, norms. Character values are taught in schools to students through several ways such as habituation, examples from teachers, school rules. There are several options for educational institutions in Indonesia, such as ordinary public schools or Islamic boarding schools with an overnight system. Boarding school is one of the educational institutions in Indonesia that uses a dormitory system. Students study and stay at school. Boarding schools in Indonesia are better known as pesantren, with good religious teaching not only teachers, school principals, heads of foundations, but also kyai figures who become role models. Initially, the teaching of pesantren was done by studying at the house of the kyai or mosque [1], but with the development of the times, a boarding school was formed which was combined with school learning called a boarding school. Pesantren not only study Islam but also learn characters such as patience, compassion, responsibility, respect. [2] Boarding schools in Indonesia have a good impact on social life, boarding school students learn Islam, character, and school lessons that will benefit them. Students after graduation are not only religious leaders but agents of social change in society.

During the covid-19 pandemic, public schools used to carry out digital learning, but boarding schools still carried out faceto-face learning. Some schools find it difficult to assess students, especially character assessments. Prior to the covid-19 pandemic, this character issue was discussed in research, media, and government regulations. In the covid-19 pandemic, character education becomes more difficult because students and teachers do not do direct learning. Boarding schools continue to carry out direct learning, because the boarding school system must stay at school. Character building is carried out by instilling good habits and carrying out activities towards character 
education such as praying in congregation, reciting the Koran and memorizing. Students in boarding schools are far from negative influences, a supportive environment, peers who have the same norms, morals strongly support students to be good. During the current pandemic, it is a challenge for boarding schools to remain an educational institution that can educate their students well. Boarding schools are still needed during the current pandemic, especially during the 4.0 revolution where outside influences easily enter a lot of negative things such as pornography, hoaxes, hate on social media, dirty language, addiction to online games, TV shows are not educational, so the need for good character in dealing with the situation.

The characters discussed in this paper are those of discipline and responsibility. At this time, community discipline is still lacking, simple examples are violations of the use of masks, and violations of physical distancing during the covid-19 pandemic, there are 4,009 violations in Batu Malang City. [3] This is an example of a lack of discipline in society, as well as a lack of a sense of responsibility in society in preventing health. Other data regarding the lack of discipline and responsibility is traffic violations, as many as 177,936 cases of traffic violations occurred in Jakarta in 2019-2020. [4] An example of this is the behavior of a lack of discipline and responsibility. The importance of the character of discipline and responsibility at this time. Boarding school is a good place for character building discipline and responsibility, every day they are supervised in every activity. Students at boarding schools take care of their own lives, adhere to school schedules, dormitories so that discipline and responsibility are needed.

Baituilmi Boarding School is a formal educational. The vision of the school is "The realization of a Quran generation that excels in achievement and has Islamic character. Based on the sense of responsibility and concern of the foundation's management for the development of the world of education in Indonesia, which is experiencing dynamics and challenges that are not light, especially in the field of morality/personality and the development of human resources potential. In the year of 2015 SMP IT Baitul Ilmi (Islamic Boarding School) was established, using a combination of the Education Office curriculum and the Islamic boarding school curriculum, especially Tahfidz Quran, it is hoped that it will be able to make the students have a balance in maintaining and developing their potential and producing graduates who are ready to continue to a higher level with the main provisions in the form of a straight Islamic aqidah, true worship, noble character and general knowledge in accordance with developments and needs. Based on this vision, students at the Baituilmi boarding school learn the Quran by memorizing and applying its contents to life. In addition to creating a generation of Quran, this boarding school creates a generation with Islamic character. Generations with Islamic morality certainly have good characters such as compassion, religion, discipline, and responsibility. Students at boarding school and overnight stays are certainly very good at applying discipline and responsibility. There are three formulations discussed in this study (1) How is the special program at Baituilmi boarding school in fostering the character of discipline and responsibility?, (2) How is the achievement of the program in fostering the character of discipline and responsibility?, (3) What are the obstacles and efforts to resolve the implementation the special program in fostering the character of discipline and responsibility? This research is intended so that the character of the discipline and responsibility of the Indonesian nation is better through the output of boarding schools.

\section{THEORETICAL REVIEW}

\subsection{Boarding School}

\subsubsection{History of Boarding School}

Initially boarding school is a traditional pesantren. When viewed from the history of Islamic education in Indonesia. Pesantren is a place of Islamic education in Indonesia with a simple system. There are five elements that are owned by the pesantren, namely kyai, mosque, santri, recitation, and boarding school. [1] Starting from the hut where they live as a dormitory, there is a mosque as a place of study and worship, then the figure of the kyai who becomes a role model, the students who become students in that place are very obedient to the teacher or kyai, recite the Koran and memorize Quran and other books Education in pesantren is very simple, there are no lessons about the world, they only study religion by studying the Quran the yellow book, hadith. However, with the development of the times, the pesantren turned into a boarding school with modern management, not only studying religion but learning other sciences. There are several types of pesantren, there are those who learn by (1) students with the kyai face-to-face or together, (2) students stay at the cottage and then study at the boarding school, (3) students stay at the cottage but go to school elsewhere. [5]. In the current era, there are many boarding schools in Indonesia, they become places for social change and are expected to become character builders for the nation's children. 


\subsubsection{Boarding School in Discipline Responsibility Character Habituation}

Boarding School is a place of habituation for students in living their lives either individually or socially. Habituation connects the individual and the social. [6] At the Boarding School, students learn about their experiences in social relationships, in simple terms, students relate to their peers at the boarding school, then relate to teachers, hostel supervisors, and other school members. The values in the school make students have the character of discipline and responsibility. Students are accustomed to obeying the time rules at school appropriately and if they are late they will be exposed to relationships so that students are more responsible for their obligations to comply with time. Student life in the dormitory also trains discipline and responsibility, students must wash and clean their own dorm room or clean the dormitory extensively with their friends. These habits are expected to exist in students until adulthood, because after students graduate they are in a society that has different values and norms at school because the rules outside are different from those at school. If they get bad friends, their attitude can change because they follow the rules of the wrong group or friends. [7].

\subsection{Citizenship Theory}

Researchers enter the perspective of citizenship theory because the field they take is a master of civic education, boarding schools in carrying out their duties as educational institutions of course they instill character values, schools as educational institutions not only instill knowledge but character values. When viewed from citizenship theory, there is a link between value education with commutarian and neorepublican theories, where in commutarian there are values that must be obeyed by every society, things that are considered good are determined, for example in Indonesia religious values become very important values, violations of values and norms must be eliminated [8], however, when viewed from a neorepublican perspective where there is an aspect of pluralism and equality in political rights, boarding school also implies pluralism such as how students are required to respect other students of different ethnicity because boarding schools tend to have heterogeneous students. We know that students at boarding schools have different ethnicities, so the need for the value of existing pluralism to establish good relations with other students, because if students do not have tolerance then there is no harmony.

\section{METHOD}

This study uses an approach this selection approach because the approach can describe the character building of discipline and responsibility in the Baituilmi Islamic Boarding School. This research approach uses a qualitative approach, because it understands individuals and groups as social problems. [9]

The method used by researchers in this study is a case study, because character is a problem that needs to be studied as an effort to improve the character of discipline and responsibility in a good direction. The unique condition of this research is that the boarding school as the place of research is a school with good character building, and this research describes an agency, namely boarding schools carry out coaching, while the case in this study is the lack of awareness about the character of discipline and responsibility.

Participants were informants who were involved in the research consisting of the Principal, Dormitory Supervisor, several students, and parents, and the place of research was Baitulilmi Boarding School located in Gasol Village, Gasol Village, Cugenang District, Cianjur Regency. The data collection technique used observation where the researcher saw firsthand the spaciousness of the condition of the school, in addition to observations there were interviews with the principal, dormitory administrators, several students, and parents, as well as some documentation. Research data analysts use data reduction, data presentation, and drawing conclusions, research verification using triangulation and member checks

\section{RESULTS AND DISCUSSION}

\subsection{How is the special program at Baituilmi boarding school} in fostering the character of discipline and responsibility?

The special program at the Boarding School is divided into several programs such as (1) reciting the Quran and memorizing it. By memorizing the Quran, students are disciplined because memorizing the Quran needs to be done carefully and carried out every day, (2) praying in congregation, students are required to pray together every day. days so that it fosters discipline in students, (3) dormitory activities also encourage discipline and responsibility for students, there are scheduled cleaning activities for students where they are required to clean the dormitory according to the schedule provided if they don't do it then there is a penalty they get. Students learn to be independent such as washing their own clothes, washing their own dishes, and cleaning their own house. In addition there are rules for both students and teachers in the school. Students enter class on time and there is no reason to be late, as well as their teachers must be absent before learning. Extracurricular activities are also required to carry out discipline such as scouts taught for discipline and responsibility, as well as other activities such as extracurricular activities in the field of sports that are required to come on time and take responsibility in their extracurricular activities. 
According to Maksudin of the Boarding School, the advantages of boarding schools include: (1) there are far fewer classes than other schools, because they want teachers who focus on each student, and if they are few in number, they are more focused, (2) the quality of education and student expertise is the main priority. for students not only knowledge but expertise, (3), sources of adequate facilities in schools from sports venues, arts venues, other facilities that support students, (4) boarding schools are a challenge for students because they have to be independent, ( 5 There are many subjects or skills that students can choose to develop their potential so that the potential students have can develop well. [10]

Boarding schools have good activities in fostering the character of discipline and responsibility, Baituilmi has several advantages such as not many students in class, Batuilmi also instills independence in students so as to foster discipline and responsibility characters.

Table 1. Activities boarding school

\begin{tabular}{|l|l|}
\hline \multicolumn{1}{|c|}{ Activity } & \multicolumn{1}{c|}{ Time } \\
\hline Tahajjud prayer & $3.00 \mathrm{am}$ \\
\hline Fajr Prayer & $5.00 \mathrm{am}$ \\
\hline $\begin{array}{l}\text { Take a shower and have breakfast } \\
\text { and clean the dormitory }\end{array}$ & $5.30 \mathrm{am}$ \\
\hline Briefing before school & $7.45 \mathrm{am}$ \\
\hline Scholl & $8.00 \mathrm{am}$ \\
\hline Dzuhur prayer & $12.00 \mathrm{pm}$ \\
\hline School & $1.00 \mathrm{pm}$ \\
\hline Break and Ashar pray & $3.00 \mathrm{pm}$ \\
\hline Recite and memorize the Quran & $4.00 \mathrm{pm}$ \\
\hline Preparation for Maghrib prayer & $5.30 \mathrm{pm}$ \\
\hline Magrib prayer & $6.00 \mathrm{pm}$ \\
\hline Dinner & $6.30 \mathrm{pm}$ \\
\hline Isya prayer & $7.00 \mathrm{pm}$ \\
\hline Yellow book learning & $7.30 \mathrm{pm}$ \\
\hline Sleep & $10.00 \mathrm{pm}$ \\
\hline
\end{tabular}

At a dormitories, students are required to be disciplined and responsible for carrying out their duties properly after waking up, praying Tahajud, and praying at dawn, students are required to clean the dormitory with a schedule that has been provided by the hostel, students and students are separated, for room cleanliness is an obligation for each room while for corridors and other parts of the dormitory are divided into several picket sections. The coaches and students continue to make the dormitory climate comfortable. Dormitory residents try not to create conflicts between students, conflicts can occur from existing conflicts. [11]. According to Farida, the purpose of boarding schools in Indonesia is to have good character and have faith in God Almighty. [12]
Discipline character is part of obedience, responsibility and self-control. [13] Discipline character is part of obedience, responsibility and self-control. That means that the character of discipline means the character of being obedient and carrying out according to the rules. While the character of responsibility itself is a character with the characteristics of obeying the rules and caring about obligations. [14] Boarding schools are very good in fostering the character of discipline and responsibility, in addition to fostering the character of discipline and responsibility can also be part of the implementation of civic education where such coaching can form good citizens, and one of the characters of good citizens is responsibility. [15]

Character education directs students to behave well. [14], but not only well-behaved at times, but well-behaved forever. Students behave well because they like to do good, not because they fear punishment and want rewards. Students must carry out the character of discipline and responsibility consciously through their thoughts. If they are disciplined and responsible only because they are afraid of punishment, they will obey if only someone is watching, for example a motorcycle rider who wears a helmet for fear of being ticketed by the police. Habituation at school through the conditions of school habits. Each school has a habituation that is different from other schools, some are academic, some are cultural, and some are character. Boarding school is a school that prioritizes religious values and character, especially the character of discipline and responsibility, but other aspects are also not left behind, such as aspects of knowledge, and aspects of skills for students.

\subsection{How is the achievement of the program in fostering the character of discipline and responsibility?}

The achievement of the program in fostering the character of discipline and responsibility is quite good. Student activities are scheduled. Starting with the tahajjud prayer together at night, of course you need discipline and responsibility in carrying it out. Interviews with students stated that their activities were neatly arranged and activities were carried out well. Interviews with other students also have the same explanation where they are more scheduled in their lives when they enter boarding school, here I have to carry out my assignments on time properly. During the semester break I also carry out activities well because I am used to scheduling activities. Habituation carried out at boarding schools makes students more disciplined and responsible in carrying out their duties. Parents of students also explained that their children were better after being in boarding school, my child after several semesters in a boarding school environment became better. At the boarding school they are trained to carry out their duties properly and correctly so that it is embedded in them. It is hoped that a good output will be created when they leave the boarding school. Because many pesantren outputs are not good because of outside influences, considering the difference in social values at boarding schools with social values 
outside. Output means school graduates. [16]. Because students who pass boarding school can get bad external influences, there are many violations of values, morals and norms that occur outside the boarding school such as corruption, free sex, violating traffic rules. They are actually good agents of change for the outside community, because they have studied religion properly and correctly and have better religious values than other people who have not studied religion.

The fostering of discipline and responsibility at Baituillmi can create good citizens, although Baituillmi carries out discipline and responsibility character building with activities but they can form good citizens, namely students obey the rules of boarding school and in adults they obey the constitution and citizens A good state is a citizen who obeys the constitution. [17] Discipline and responsibility character building at Baituilmi is part of character education, and citizenship education is different from character education but different, namely character education is more on personal character while citizenship education is part of public character [18]

\subsection{What are the obstacles and efforts to resolve the} implementation the special program in fostering the character of discipline and responsibility?

Obstacles in the implementation of the program, according to the principal, such as water problems are the only obstacle, there are no other problems, because of the water problem, the students were late for class. The teacher explained that there was no significant problem in implementing learning, only the problem of water which caused students to be late for class. The problem can be solved quickly. In addition to the above problems, there are some students who lack discipline at the beginning of school. Because they are not used to the life of a boarding school, students become less comfortable. The solution can be in the form of counseling guidance, where the counseling supervisor has a conversation with the student. Counseling teachers must have empathy to their students. Students have a good sense of security so they feel at home in schools and dormitories. In addition, students are not allowed to leave the school environment, so it can cause students to feel bored because they are constantly in the same environment. The teacher carries out learning outside the classroom so that students feel more comfortable. For example, the teacher provides learning about nature so that students do not feel bored. Parents also play a role in solving solutions where the school is given a report every semester on the achievement of student results. Schools and parents cooperate with each other in solving problems experienced by students, looking for solutions on how to solve student problems. Students are kept under control of their progress by parents, with reports received by parents. Schools and parents have a good relationship, schools educate their students to be better, while parents support their children to stay enthusiastic in learning. Parents must direct their children to good character, set a good example when the child is at home, so that there is harmony in values between school and parents.

The study on the role of boarding schools in improving the discipline of students to become good citizens, explains that many students are less disciplined in regulations. There are many obstacles in coaching at the boarding school, such as the condition of the students who are not comfortable, and the students have not been able to live independently. Through the rules of the boarding school, it is hoped that these problems will be overcome, besides that positive student activities can also help [19]

\section{CONCLUSION}

Baituilmi Boarding School is a boarding school with a vision of "The creation of a Quranic generation that excels in achievement and has Islamic character". This boarding school has a "morals" program which consists of the adaptation stage, the habituation stage, the understanding stage, the caring stage, the leadership stage, and the future orientation stage. The program is carried out through habituation such as pesantren activities, namely tahfidz Quran, dormitory activities such as Tahajud prayers, boarding pickets, classroom learning, extracurricular activities, and other activities such as religious discussions. This activity trains students' discipline and responsibility characters so that students who study at the Baituilmi boarding school increase their discipline and responsibility attitude. The development of the character of discipline and responsibility possessed by students goes well through activities carried out at the Baituilmi boarding school.

\section{AUTHORS' CONTRIBUTIONS}

All authors contribute both in writing and research ideas in making this paper.

\section{ACKNOWLEDGMENTS}

Thank you to the Baituilmi boarding school which has helped in the research process and to my parents who provide support. 


\section{REFRENCES}

[1] The Ministri of Religion of The Republic of Indonesia, Pola pengembangan pondok peantren, The Directirate of Islamic Religious Indonesia, 2003.

[2] M. Faidah, A. Puspitorini, F. P. Wijayanti, M. P. Ilmi. Empowerment of Islamic boarding school student based on the local potential in Indonesia, in Proceedings of the international Join Conference on Arts and Humanities (IJCAH), Atlantis Press, Surabaya, Universitas Negeri Surabaya, 2020, pp. 1444-1448. https://dx.doi.org/10.2991/assehr.k.201201.244

[3] E. D. Kusuma, A. Wahid, D. Ismaeni, Penerapan sanksi pelanggaran physical disctanting dan penggunaan masker berdasarkan Perwali Batu Nomor 78 Tahun 2020, vol 27, pp. 876-889, 2021

[4] N. P. Saputra, Ekectronic traffic law enforcement dan permasalahanya, vol 8, pp. 1-6, Apr. 2021

[5] L. Hakim, Pola pembelajaran di pesantren, The Directorate of Islami Religious Institusion, 2010

[6] Bourdieu, In other words: essay towards a reflekstive sociology, translated by Maathew Adamson, Standford University Press, 2009

[7] M. Syukur, Rifal, Amirullah, F. Widyawati, Education Problems at Darul Huffadh Islamic Boarding School in Bone Regency, Sulawesi Selatan, Indonesia, in Proceeding of the $3 \mathrm{rd}$ International Confrence on Social Science (ICSS), Atlantis Press. Maksasar. Universitas Negeri Makasar, pp 530-533 DOI: https://dx.doi.org/10.2991/assehr.k.201014.116

[8] A.A. Wahab, Sapriya, Teori Landasan Pendidikan Kewaranearaan, Alfabeta, 2011

[9] J. W. Cresweel, Research design: pendekatan metode kualitatif, kuantitatif, dan campuran, Pustaka Belajar, 2016

[10] Maksudin, Pendidikan Nilai Sistem Sekolah Boarding School di SMP IT Abubakar. (Rencana Disertasi). Sekolah Pasca Sarjana. Universitas Sunan Kalijaga. Dissertation. Universitas Sunan Kalijaga

[11] R. Utari. M. Sutapa. T. Rahmawati, Pembentukan iklim sosial akademk di asrama hawasiswa, vol 19, Pp 12-23, April, 2014.

[12] Faridah. Asrimunandar, Bernard. Sekolah Berasrama di Sulawesi Selatan, vol, pp 142-251, 2018
[13] J. Caturiasari, Implementaisi pembelajaran PKn dalam budaya lingkungan boarding school untuk meningkatkan karakter tanggungjawab dan disiplin. Theses. Universitas Pendidikan Indonesia. 2017.

[14] F, Mayar. Character of Discipline in Learning Drawing. In Wadim Strielkowski, Proceedings of the International Conference of Early Childhood Education (ICECE 2019 Padang, Universitas Negeri Padang, pp 47-50 https://dx.doi.org/10.2991/assehr.k.200715.010

[15] Wuryan dan Syaifullah, Ilmu kewarganegaraan (Civics), Civic education laboratory, 2013

[16] F. A. Yahya. Problem manajemen pesantren, sekolah dan madrasah: problem mutu dan kualitas input proses output, vol 8. pp 93-109, 2015.

[17] D, Heater, A brief of citizenship. new york University.2004

[18] A, Schools, The heart of the matter: character and citizenship education in alberta schools, Albert, 2005

[19] M, Septiyandi, Studi tentang peran ponpes dalam meningkatkan kedisiplinan santri agar menjadi warga negara yang baik. (Theses). Univeristas Pendidikan Indonesia. 2015 